\title{
Improve Organizational Performance by implementing Competency Based Empowerment for Employees
}

\author{
Budiman \\ UIN Sunan Gunung Djati Bandung, Indonesia \\ Email: budiman@uinsgd.ac.id
}

\begin{abstract}
This study aims to analyze empowerment strategies for increasing employee competence. This research uses a qualitative approach and descriptive methods. The data were obtained through a literature review and analyzed descriptively and qualitatively. The results showed that employee competence could be improved through employee empowerment, such as: providing information on employee competencies; creating a culture of organizational climate that supports optimal employee competence; provide full support to employees so that they can serve their roles and actualize their competencies optimally; encourage participation in organizational activities; provide access to the widest possible information; encourage the growth of innovation by enabling and providing opportunities to express every innovative and potential idea that can enrich their competence, and encourages high accountability.
\end{abstract}

Keywords: Competence, Performance, Empowerment, Employees.

\section{A. INTRODUCTION}

Every organization has a goal of realizing growth and survival in the long term (Thoyib, 2005). In a global era marked by a complex business environment, companies and organizations always face fundamental problems or challenges, namely how to survive in the present while facing future competition (Wardani, 2018). This has spurred every company always to be able to improve its performance. Company performance is always a measure of the performance of the market of the company. Performance measurement aims to compare the current achievements with the previous year or the achievements of competitors (Sulistyawati \& Indrayani, 2012). By knowing its performance, companies can make revisions to irrelevant policies so that future achievements will be better (Purba \& Munawar, 2008).

For the organization's performance or company to increase, the organization must create what is known as an organizational competitive advantage that differentiates the organization from others (Wagner III \& Hollenbeck, 2014). When an organization or company can do something, and another company cannot, or has everything its rivals want, it represents a strategic edge (Adiputra \& Mandala, 2017). The long-term sustainability of a company needs and retains a strategic edge. The search for competitive advantage consists of the success and loss of organizations. Researchers and practitioners of strategic management want to understand the 
essence and role of competitive advantage in different industries (Covin \& Miles, 1999).

In general, a company can only retain a competitive advantage for some time when it is imitated and undermined by rivals (Coyne, 1986). So, a strategic edge is not necessary. Companies need to search for a strategic edge by continuous adaptation to international patterns and events (Salunke et al., 2011; Putera et al., 2014). For the competitive advantage to be sustainable, reliable strategic human resource management is needed to maximize all the potentially available resources. The biggest resources an organization has are human resources or employees of a company (Larasati, 2018)

Every organization, including business organizations, really needs employee performance to support its performance. However, in reality, many employees cannot meet the organization's standards or work targets to not contribute to the organization optimally (Riniwati, 2016). This is partly due to employees' inadequate competence due to the lack of empowerment carried out by organizational authorities, especially company management (Sunarsi, 2018).

Most organizations ignore human resource development as a major asset. Elnaga \& Imran (2013) states that business in an organization is filled with uncertainty about understanding employee contributions in increasing organizational productivity and profitability. This causes a lot of less-skilled workforce, uncompetitive organization, high levels of poor performance, and low productivity. The organization makes various efforts by emphasizing its employees related to improving performance for beneficial outputs and outcomes as long-term effects. HR management efforts aim to improve employees' ability to take up different roles to enhance corporate competitiveness and environmental adaptation, in particular external instability, and to benefit workers to advance their jobs, improve their skills, and improve their talent (Mulyana, 2010).

Empowerment improves efficiency with happy consumers of good quality, which has a positive effect on the market. In line with what is stated by Pfeffer (1998) that "the key to long-term success has been, and will continue to be, how organizations manage their employees, because creating meaningful work and otherwise keeping employees happy is central to fostering organizational effectiveness."

Often firms experience serious obstacles in managing employees to work optimally. In line with Moynihan \& Pandey (2007) that "the basic challenge for all organizations is" induce your workers to follow corporate goals." In fact, to achieve long-term and sustainable success, organizations need empowerment that creates meaningful work (according to employees' talents and competencies). In addition to talent and competence, organizations need to pay attention to aspects of employee resilience or resilience in working so that an organization continues to exist in the long term. 


\section{B. METHOD}

This analysis employs a qualitative and descriptive approach. According to Moleong (2007), qualitative science seeks to explain the phenomenon observed, holistically and thorough explanations in word and phrase, by test subjects such as acting, interpretation, inspiration, behavior, etc. By using multiple natural processes, peculiar existence. The goal of qualitative analysis is to describe an in-depth phenomenon by the compilation of data, which demonstrates that the detail and depth of the data under study are significant (Sugiyono, 2011). Data from different corresponding kinds of literature collected by literature review were then evaluated descriptively. The analysis would be the definition, and later on, the author explains the problem solved by explaining or describing, based on the details that appear or present, the state of the research object (Nawawi \& Martini, 1996).

\section{RESULT AND DISCUSSION}

Empowerment is the mechanism by which managers help others acquire and use power to decide about themselves and their jobs. Empowerment is also a mechanism affecting workers by an inclusion process (Rifa'i, 2017). Moreover, empowerment is a type of decentralization involving subordinate decision-makers. In the broadest context, empowerment is a mechanism that provides workers with more autonomy by exchanging relevant knowledge and managing work performance variables. Empowerment aims to reduce circumstances that contribute to helplessness and improve employee self-success feelings. Empowerment is the employee's authority to manage circumstances and monitor conflicts (Greenberg et al., 1993).

From a psychological perspective, empowerment is a form of intrinsic motivation because carrying out a task is an appreciation and provides intrinsic satisfaction in the form of pleasure, artistry, achievement, increasing knowledge and skills, self-disclosure, avoiding frustration, boredom, and anxiety in the workplace; Which level of employee confidence influence the work environment, ability, value of the work and presumed autonomy in work (Ratnawati, 2004).

The empowerment process can use several approaches, namely: (a) assisting employees in achieving mastery of performance (providing appropriate training, training, and experience directed at results as the start of success); (b) allow better monitoring (to take into account job efficiency and then to assist them in producing accountable results); (c) provide models of progress that would enable them to observe peers who have contributed to work success); (d) employ social reinforcement and persuasion (to offer thanks, promote and provide input in support to develop self-confidence); (e) providing a reduction of stress and anxiety through better job definition, task assistance, and honest handling.

Empowerment will grow and flourish if an organization promotes engagement: (a) Employees should be allowed to take up their employers. Employees ought to be concerned with strengthening work and organizational working relations; (innovation). The world should be open or accessible to people 
with creative ideas and inspire people, at logical costs, to try new approaches and take appropriate risks. When interest is measured as a technological skill, the empowering atmosphere is developed (access to information). Employees need to have access to a variety of results. In this situation, the person must determine what knowledge is required to complete the work; and (d) obligation. Empowered workers must bear responsibility for their actions, deliver accepted outcomes, gain a reputation, and act in favor of others.

Empowerment is the key to employees' motivation and productivity who feel they have value and contribute to being willing to help and develop at work. Empowerment allows a person to develop personally and professionally so that his contribution to the world of work will be maximum. The results showed that empowerment affected competence (Daly, 2005).

Competence is a core attribute of an individual, which is a way of acting and thinking in all circumstances that lasts for a long time. Competency is often the success of an individual in a job seen in perception, actions, and attitudes (Kartika \& Sugiarto, 2014). Dewiyana (2006) notes that the capacity to perform cognitive, affective, and psychomotor actions is the intelligence, skills, and capacities that an individual is masterminded by, whether he is part of his/her self. Furthermore, competence may be construed as defining both qualitative and quantitative qualifications or abilities of a person. The willingness to do what the work of an enterprise demands is also the capacity of anyone to ensure that its intended goals are accomplished (Bassellier et al., 2001). Competence is a community interrelated to an individual, a team, or an organization's expertise, skills, and abilities for efficient results. A variety of competencies are significant for most organizations' quality and success (Lasmaya, 2016).

There are different facets of competence: (1) the capacity (skill) of an individual to perform an assigned task or work. E.g., employees' conduct norm is more effective and efficient at selecting work methods; (2) intelligence (knowledge), especially knowledge in the cognitive field. For example, an employee learns how to recognize learning, and how to learn according to existing business needs; (3) recognizes the depth of individuals' cognitive and affective abilities. An employee who carries out schooling, for example, must accurately and efficiently grasp the characteristics and conditions of work; (4) meaning is a quality of conduct believed and psychologically integrated into the worker. E.g., employee conduct expectations in the fulfillment of their tasks (honesty, openness, democracy, etc.); (5) attitude, namely, feeling (happy, uncomfortable) or response to an external stimulus. E.g., responses to the economic recession, pay increases; (6) demand (interest) appears to be an action. For example, to do a job.

Besides, competence also has several indicators as follows: (a) individual skills, including (1) ability to complete tasks well; (2) ability to solve problems; (3) ability to determine priority problems; (4) the ability to provide service information (b) knowledge related to work, which includes: (1) the experience and understanding of the roles and activities of agency organizations in their respective 
fields; (3) the knowledge of how relevant and accurate material, resources, and techniques can be used; (c) the attitude at work including (1) innovation at work; (2) high moral; (3) planning/organization capacity.

Competence consists of: (1) planning competence, such activities such as setting goals, evaluating risks and creating a series of actions to accomplish objectives; (2) power competence, actions such as making an effect on others, forcing certain actions or taking certain decisions, and providing motivation to move towards organizational objectives; (3) leadership abilities, speech skills, listening skills; (4) organizational skills, including: empathy, consensus building, networking, communication, communication, leadership, crisis management, consideration for others, and becoming a team player; (5) competency thought, strategic thinking, critical thinking, attention to action, the need for logical skills, the recognition of correlations and the development of new ideas; (6) organizational competence, which is the capacity to: schedule work, coordinate personnel, conduct work, evaluate success and take measured risks; (7) competency in the management of human resources, which is the ability in the areas of: team building; commitment motivation, talent growth, performance input and diversity appreciation; (8) leadership competence, including self-positioning skills, professional growth, transformation management, strategic alignment, mission creation, future planning, change management and pioneering wellbeing at the workplace; (9) client service competence, which is competence in the context of: customer recognition and analysis, service and implementation orientation, collaborating with clients; (10) Business expertise, which includes: financial management, business decision-making capabilities, machine work, business acumen, business decision-making and incomegenerating skills; (11) self-management competence, self-motivated competence, confidence-building, self-learning, resilience and initiative management; (12) technical/operational skill, competence relevant to the execution of office activities, dealing with electronic technology, using other tools, showing technical and practical knowledge and making use of statistics and numbers (Delany, 2017).

Individual competence can be defined as (a) intellectual competence is the essence of an individual's conduct and behavior, or the will and intellectual ability of an individual (maybe in the context of information, abilities, technical comprehension, mental understanding, etc.) that are relatively stable when faced with challenges in the workplace, arising from the synergy between the nature of the work. Internal drive and the ability for qualitative knowledge; (b) Emotional maturity is the character of the attitude and actions or the desire and capacity to regulate oneself and to consider the world critically and morally, such that the emotional pattern is reasonably consistent in coping with issues at the workplace, which is shaped by the synergy of self-conceptual characteristics. External inspiration, as well as emotional knowledge capabilities; (c) Social competence, is the character of attitude and actions or desire and the ability to create cooperative nodes with others that are reasonably secure when confronted with problems in the workplace that are created by synergies between character, self-concept, internal 
motivation and capacity for intellectual, social awareness. Thus, competence is a collection of knowledge of a person that comes from his/her expertise/skills, preparation, and experience so that he/she can carry out his/her duties in a competent manner to achieve defined goals that are expressed in his/her awareness, talents, interests and skills.

Employee competence is a need that cannot be negotiated because its existence is essential and vital for the achievement of organizational performance. Therefore, employee competence needs to be continuously improved, including through empowerment programs. For business organizations, employee empowerment efforts can be made by direct and indirect supervisors of employees, either at the supervisor, manager, or leadership level. Empowerment strategies that can be considered to improve employee competence include:

There is a strengthening of employees' overall competence to solve various problems that arise and can meet the organization's actual needs. Competency strengthening can be done through various training activities and workshops involving experts and providing special rewards for high achieving employees.

Creation of a culture or organizational climate that allows potential employees to develop optimally to support the actualization of their competencies. In this context, social interactions and relationships between employees and leaders at all levels need to be managed so that employees can calmly, comfortably, and freely carry out their roles as members of the organization. This condition will encourage employee competence to grow better.

Provide full support to employees so that they can play their duties and actualize their competencies optimally. Support can be done by giving employees full autonomy and flexibility to play their roles and responsibilities as employees. Encourage employee participation in various organizational activities. At this level, employees are given the widest possible opportunity to express their aspirations as members of the organization with de facto contributions to the organization. In fact, employees also need to be given the freedom to have massive social interactions with leadership elements at all levels as a manifestation of their active participation.

Provide the widest possible access to information to employees. Employees' competencies can't be enriched and improved without the supply of new and up-todate information, knowledge, and technology. Therefore, the organization needs to facilitate employees to get as much information as possible through various possible networks.

Encouraging the growth of innovation among employees by freeing employees to develop innovative and creative ideas that can enrich their competence. Renewal of approaches, methods, techniques, strategies, or work patterns clearly requires the contribution of innovative and creative ideas from employees, which can only grow if given opportunities and a conducive atmosphere for employees to innovate. Encourage employees to have high accountability. Employees must have responsibility for various actions taken as members of the organization, which are reported regularly and gradually on a tiered basis to the 
supervisor. Accountability will encourage employees to have better competence as a form of anticipation for fulfilling responsibilities.

\section{CONCLUSION}

Organizational performance can be achieved through enrichment and enhancement of employee competencies, which can be done through empowerment with the following strategies: providing strengthening of employee competencies; creating a culture of organizational climate that allows potential employees to develop optimally; provide full support to employees so that they can perform their duties and actualize their competences optimally; encourage employee participation in various organizational activities; provide the widest possible access to information for employees; encouraging the growth of innovation among employees by freeing employees to come up with innovative and creative ideas that have the potential to enrich their competence, and encourage employees to have high accountability.

\section{REFERENCES}

1. Bassellier, G., Reich, B. H., \& Benbasat, I. (2001). Information Technology Competence of Business Managers: A Definition and Research Model. Journal of Management Information Systems, 17(4), 159-182.

2. Covin, J. G., \& Miles, M. P. (1999). Corporate Entrepreneurship and The Pursuit of Competitive Advantage. Entrepreneurship Theory and Practice, 23(3), 47-63.

3. Coyne, K. P. (1986). Sustainable Competitive Advantage-What it is, what it isn't. Business Horizons, 29(1), 54-61.

4. Daly, H. (2015). Pengaruh Kompetensi, Disiplin dan Kompensasi Terhadap Kinerja Pegawai Badan Pemberdayaan Perempuan dan Keluarga Berencana Daerah Provinsi Sulawesi Tengah. Katalogis, 3(1).

5. Delany, F. N. (2017). Pengaruh Budaya Organisasi dan Kompetensi Karyawan Terhadap Efektivitas Kerja di PT. Industri Telekomunikasi Indonesia (Inti) Persero Bandung. (Doctoral dissertation, Fakultas Ekonomi dan Bisnis Unpas Bandung).

6. Dewiyana, H. (2006). Kompetensi dan Kurikulum Perpustakaan: Paradigma Baru dan Dunia Kerja di Era Globalisasi Informasi. Pustaha, 2(1), 22-31.

7. Elnaga, A., \& Imran, A. (2013). The Effect of Training on Employee Performance. European Journal of Business and Management, 5(4), 137-147.

8. Greenberg, J., Baron, R. A., \& Grover, R. A. (1993). Behavior in Organizations: Understanding and Managing the Human Side of Work. Boston: Allyn \& Bacon.

9. Kartika, L. N., \& Sugiarto, A. (2014). Pengaruh Tingkat Kompetensi Terhadap Kinerja Pegawai Administrasi Perkantoran. Jurnal Ekonomi dan Bisnis, 17(1), 7390.

10. Lasmaya, S. M. (2016). Pengaruh Sistem Informasi SDM, Kompetensi dan Disiplin Kerja Terhadap Kinerja Karyawan.Jurnal Ekonomi, Bisnis $\mathcal{E}$ Entrepreneurship, 10(1), 25-43.

11. Moloeng, L. J. (2007). Metodologi Penelitian Kualitatif. Bandung: Remaja Rosdakarya. 
12. Moynihan, D. P., \& Pandey, S. K. (2007). Finding Workable Levers Over Work Motivation: Comparing Job Satisfaction, Job Involvement, and Organizational Commitment. Administration \& Society, 39(7), 803-832.

13. Mulyana, M. (2010). Manajemen Sumber Daya Manusia (SDM) Ritel dalam Meningkatkan Kinerja Perusahaan. Jurnal Ilmiah Ranggagading, 10(2), 164-170.

14. Nawawi, H., \& Martini, M. (1996). Penelitian Terapan. Yogyakarta: Gadjah Mada University Press.

15. Pfeffer, J. (1998). Seven Practices of Successful Organizations. California Management Review, 40(2), 97.

16. Purba, J. H. V., \& Munawar, A. (2008). Kajian Dampak Pelatihan terhadap Kinerja Karyawan. Jurnal Ilmiah Ranggagading (JIR), 8(2), 95-102.

17. Putera, G. R., Tama, I. P., \& Efranto, R. Y. (2014). Perencanaan Strategi Bisnis dengan Menggunakan Strategy-formulation Framework Guna Meningkatkan Keunggulanbersaing (Studi Kasus: Koperasi Unit Desa "Batu”). Jurnal Rekayasa dan Manajemen Sistem Industri, 2(1), 207-218.

18. Ratnawati, I. (2004). Upaya Pemberdayaan Karyawan: Suatu Pendekatan Untuk Menumbuhkan Motivasi Kerja Intrinsik. Jurnal Studi Manajemen dan Organisasi (JSMO), 1(1), 56-63.

19. Rifa'i, A. (2017). Peran Bank Pembiayaan Rakyat Syariah dalam Mengimplementasikan Keuangan Inklusif Melalui Pembiayaan UMKM. Human Falah: Jurnal Ekonomi dan Bisnis Islam, 1(1).

20. Riniwati, H. (2016). Manajemen Sumberdaya Manusia: Aktivitas Utama dan Pengembangan SDM. Malang: Universitas Brawijaya Press.

21. Salunke, S., Weerawardena, J., \& McColl-Kennedy, J. R. (2011). Towards A Model of Dynamic Capabilities in Innovation-Based Competitive Strategy: Insights from Project-Oriented Service Firms. Industrial Marketing Management, 40(8), 1251-1263.

22. Sugiyono, S. (2007). Metode Penelitian Kualitatif Kuantitatif dan $R \mathcal{E}$ D. Bandung Alfabeta.

23. Sulistyawati, A. I., \& Indrayani, R. A. (2012). Pengaruh Kepuasan Karyawan, Training, Turnover, dan Produktivitas Karyawan terhadap Keunggulan Bersaing melalui Kinerja Perusahaan. Jurnal Dinamika Akuntansi, 4(2).

24. Sunarsi, D. (2018). Pengembangan Sumber Daya Manusia Strategik \& Karakterisrik Sistem Pendukungnya: Sebuah Tinjauan. Jurnal Ilmiah MEA (Manajemen, Ekonomi, \& Akuntansi), 2(3), 178-194.

25. Thoyib, A. (2005). Hubungan Kepemimpinan, Budaya, Strategi, dan Kinerja: Pendekatan Konsep. Jurnal manajemen dan kewirausahaan, 7(1), 60-73.

26. Wagner III, J. A., \& Hollenbeck, J. R. (2014). Organizational Behavior: Securing Competitive Advantage. Routledge.

27. Wardani, A. K. (2018). Dormansi Organisasi di Era Globalisasi. Moderat: Jurnal Ilmiah Ilmu Pemerintahan, 4(3), 28-35. 